ture history of particles in coal-fired furnaces. If hollow silicate spheres are found in moon dust they might yield important information about the early history of the dust.

Their present colour may owe more to their having been irradiated in high vacuum than to their origin and in this respect they will differ from pfa. The colour of the latter depends on the oxidation state of iron in the silicate: predominance of ferrous gives a black and ferric a red colour.

$$
\begin{aligned}
& \text { Yours faithfully, } \\
& \text { A. B. HART } \\
& \text { E. RAASK }
\end{aligned}
$$

Central Electricity Generating Board,

Research and Development Department,

Kelvin Avenue

Leatherhead, Surrey.

${ }^{1}$ Raask, E., Fuel (in the press)

${ }^{2}$ Raask, E., J. Inst. Fuel, 11, 339 (1969).

\section{Will there be Catastrophe?}

Sir,- It seems to me that the leading article "Will there be Catastrophe?" (Nature, 223, 550; 1969) curiously misses the essential point. The last two sentences of that statement read: "The record of the past century shows how technology has prospered and how the quality of life has in the process improved. There is no reason why the same should not happen in the decades ahead, even if this does sound a little like a recipe for having your cake and eating it." But isn't it the very facts which you there state that will be the cause of virtually certain overpopulation on an immense scale and conscquent famine? The minor issues to which you refer may justify a pollyannish attitude; the dialectic consequences of technological prosperity, passed over silently in the article, hardly do.

$$
\begin{aligned}
& \text { Yours faithfully, } \\
& \text { WALTER LANDAUER }
\end{aligned}
$$

Department of Animal Genetics,

University College London,

Wolfson House. 4 Stephenson Way,

London NW1.

\section{British Quest for Uniqueness versus American Ego- centrism}

Sir,-American scientists cannot have failed to notice the prevalent British custom to use two or three initials along with surnames. Whether this is an intuitive quest for uniqueness in a country where common surnames are employed (for example, D. H. R. Barton) or whether it is deliberate, the value of this practice might well be emulated by American scientists. The more common American practice to drop or not have a middle (second) or a third name is a constant source of difficulty to librarians, indexers, editors, and all those who must use the literature. While A. Kantrowitz is "obviously" a heart specialist (to the cardiologist) and obviously a physicist to the physicists, it is not obvious to many others interested in their work which one is the author of a paper appearing in a multi-disciplinary journal.

Scientists who are just now embarking on their careers would be well advised to measure the information content of their names as they appear in indexes such as Index Medicus, Physics Abstracts, Biological Abstracts and Science Citation Index. They can easily prevent a lot of needless ambiguity and confusion.

$$
\begin{aligned}
& \text { Yours faithfully, } \\
& \text { EUGENE GARFJELD }
\end{aligned}
$$

Institute for Scientific Information,

325 Chestnut Street,

Philadelphia,

Pennsylvania 19106, USA.

\section{University News}

Mr L. R. Fletcher, director of Establishments and Organization in the Department of Education and Science, has been appointed secretary of the University Grants Committee in succession to Mr E. R. Copleston who is to retire.

Dr F. T. Haxo has been appointed chairman of the Marine Biology Research Division of the University of California, San Diego's Scripps Institution of Oceano. graphy.

\section{Appointments}

Dr R. H. Mole has been appointed director of the Medical Research Council's Radiobiology Unit at Harwell. He succeeds Dr J. F. Loutit, who wishes to return to full-time research.

Dr F. T. Last has been appointed director of the new Institute of Forestry Research established by the Natural Environment Research Council at the Edinburgh Centre for Rural Economy.

\section{Announcements}

Miss Letitia Chitty and Professor P. W. Rowe have been awarded the Telford Gold Medal of the Institution of Civil Engineers. The medal goes to Miss Chitty for her series of papers published by the institution since 1936, culminating in her review of the work of the Arch Dams Committee presented to the Conference on Arch Dams in 1968. Professor Rowe, professor of soil mechanics at the University of Manchester, wins the medal for two papers published by the institution.

Dr W. L. Law, National Cancer Institute, Bethesda, has been awarded the Alessandro Pascoli Prize for Immunology and Cancer.

Professor A. G. Rose-Innes, University of Manchester Institute of Science and Technology, is to visit Poland as a Royal Society Leverhulme Visiting Professor. $\mathrm{He}$ will lecture in the physics department of the University of Warsaw and help with research in the Institute of Physics of the Polish Academy of Sciences.

\section{International Meetings}

September 22, Future of Biophysics in the United Kingdom, London (Professor R. E. Burge, Queen Elizabeth College, Department of Physics, Campden Hill Road, London W8).

November 18, Safety as a Factor in Design and Maintenance, Scunthorpe (The Iron and Steel Institute, 4 Grosvenor Gardens, London SWl).

\section{Sabbatical Itinerants}

In the hope of providing some practical assistance in the good cause of mobility between laboratories, Nature advertises the needs for housing of families about to take up periods of sabbatical leave. To begin with, no charge will be made for advertisements like this. It is hoped that a period of experiment will show what form these advertisements could most usefully take and whether they are effective.

Wanted: London flat for visiting scientist, wife and daughter. Two bedrooms, own bathroom and toilet, fully furnished, use of garden. Early September for 1 year. Please telephone 01-349 9825.

Wanted: Furnished accommodation in or near Cambridge for 2 years from October 1969. Please contact T. L. Whateley, Box 525, AECL, Pinawa, Manitoba, Canada. 